\title{
Ginsenoside Rg1 prevents starvation-induced muscle protein degradation via regulation of AKT/mTOR/FoxO signaling in C2C12 myotubes
}

\author{
FENGYU LI, XIAOXUE LI, XUEWEI PENG, LILI SUN, SHENGNAN JIA, PING WANG, \\ SHUANG MA, HONGYAN ZHAO, QINGMIAO YU and HONGLIANG HUO \\ Laboratory of Molecular and Cellular Physiology, School of Life Science, \\ Northeast Normal University, Changchun, Jilin 130024, P.R. China
}

Received August 3, 2015; Accepted December 19, 2016

DOI: $10.3892 /$ etm.2017.4615

\begin{abstract}
Skeletal muscle atrophy is often caused by catabolic conditions including fasting, disuse, aging and chronic diseases, such as chronic obstructive pulmonary disease. Atrophy occurs when the protein degradation rate exceeds the rate of protein synthesis. Therefore, maintaining a balance between the synthesis and degradation of protein in muscle cells is a major way to prevent skeletal muscle atrophy. Ginsenoside Rg1 (Rg1) is a primary active ingredient in Panax ginseng, which is considered to be one of the most valuable herbs in traditional Chinese medicine. In the current study, $\operatorname{Rg} 1$ was observed to inhibit the expression of MuRF-1 and atrogin-1 in C2C12 muscle cells in a starvation model. $\mathrm{Rg} 1$ also activated the phosphorylation of mammalian target of rapamycin (mTOR), protein kinase B (AKT), and forkhead transcription factor $\mathrm{O}$, subtypes 1 and $3 \mathrm{a}$. This phosphorylation was inhibited by LY294002, a phosphatidylinositol 3-kinase inhibitor. These data suggest that $\operatorname{Rg} 1$ may participate in the regulation of the balance between protein synthesis and degradation, and that the function of Rg1 is associated with the AKT/mTOR/FoxO signaling pathway.
\end{abstract}

Correspondence to: Professor Hongliang Huo, Laboratory of Molecular and Cellular Physiology, School of Life Science, Northeast Normal University, 5268 Renmin Street, Changchun, Jilin 130024, P.R. China

E-mail: lify671@nenu.edu.cn

Abbreviations: UPS, ubiquitin-proteasome system; PI3K, phosphatidylinositol 3-kinase; AKT, protein kinase B; FoxO, forkhead box class $\mathrm{O}$; FoxO1, forkhead transcription factor $\mathrm{O}$, subtype 1; FoxO3a, forkhead transcription factor $\mathrm{O}$, subtype 3a; atrogin-1/MAFbx, muscle atrophy F-box; MuRF-1, muscle RING-finger protein-1; mTOR, mammalian target of rapamycin; FBS, fetal bovine serum; DMEM, Dulbecco's modified Eagle medium; Rg1, Ginsenoside Rg1

Key words: ginsenoside Rg1, proteolysis, ubiquitin, $\mathrm{C} 2 \mathrm{C} 12$

\section{Introduction}

Muscle atrophy is characterized by an increase in protein degradation and reduction in protein synthesis. It is associated with a number of human diseases and catabolic conditions, including fasting, disuse, aging, cancer, neuromuscular diseases, stroke, chronic obstructive pulmonary disease, chronic heart failure, HIV-acquired immunodeficiency syndrome and sepsis (1-5). Muscle volume shrinking and muscle weakness induced by muscular dystrophy typically disrupt and adversely affect the life of patients $(3,6-8)$. Therefore, it is essential to understand the mechanism by which skeletal muscle atrophy is regulated.

A large amount of protein hydrolysis has previously been identified to occur during muscle atrophy and the ubiquitin-proteasome system (UPS) has been demonstrated to be involved in this process (9-14). In this system, the proteins are first conjugated into multiple molecules of ubiquitin. The $26 \mathrm{~S}$ proteasome then recognizes and degrades the ubiquitinated proteins $(15,16)$. Multiple enzymes regulate the protein ubiquitination; these include E1, the ubiquitin-activating enzyme, E2, the ubiquitin conjugating enzyme and E3 ubiquitin ligases $(17,18)$. E3 ubiquitin ligases serve a major role in the specificity of protein degradation, because the specific binding between the protein substrate and E3 occurs prior to the reaction with ubiquitin $(18,19)$.

It has been demonstrated that the insulin-signaling pathway is involved in the inhibition of UPS (20). In this pathway, the phosphorylation of insulin receptor substrate is stimulated when insulin binds its receptor. Phosphatidylinositol 3-kinase (PI3K), an intracellular intermediate, is recruited to phosphorylate a serine/threonine kinase, protein kinase B (AKT) during this process. AKT then phosphorylates the forkhead box class $\mathrm{O}$ transcription factors, subtype 1 and $3 \mathrm{a}$ (FoxO1 and FoxO3a), which prevents the translocation of these factors into the nucleus from the cytoplasm. Subsequently, the expression of two muscle-specific E3 ubiquitin ligases, muscle atrophy F-box (atrogin-1/MAFbx) and muscle ring finger protein (MuRF-1) is inhibited (21-23).

Accumulating evidence suggests that the PI3K/AKT-dependent signaling pathway of mammalian target of rapamycin 
(mTOR) serves a key role in protein synthesis (24-26). Activation of mTOR enhances the activity of eukaryotic initiation factor 4E-binding protein 1 and ribosomal protein S6 kinase and, ultimately, increases protein synthesis $(11,26-28)$.

One of the most valuable herbs in traditional Chinese medicine is Panax ginseng. The main bioactive components in $P$. ginseng are considered to be ginsenosides, a class of steroidal glycosides. The ginsenoside ingredients in $P$. ginseng vary, depending on the seasons, extraction methods and cultivating soils $(29,30)$. Ginsenoside $\operatorname{Rg} 1$ is one of the main ingredients in $P$. ginseng. It has been demonstrated that ginsenoside $\mathrm{Rg} 1$ has an anti-inflammatory effect on human skeletal muscle during exercise (31). Yu et al (32) have also demonstrated that the antioxidant defense system against exercise-induced oxidative stress is strengthened by oral supplements of Rg1 in rat skeletal muscle. However, the function of $\operatorname{Rg} 1$ in the resistance to muscle atrophy remains unclear (33-38).

In the present study, $\operatorname{Rg} 1$ was observed to increase the viability of $\mathrm{C} 2 \mathrm{C} 12$ muscle cells following starvation by inhibiting the expression of MuRF-1 and atrogin-1. PI3K dependent phosphorylation of AKT/FoxO and mTOR was involved in this process, indicating that $\operatorname{Rg} 1$ may resist muscle atrophy by balancing the protein degradation and protein synthesis pathways.

\section{Materials and methods}

Cell culture. C2C12 mouse myoblast cells (American Type Culture Collection, Manassas, VA, USA) were maintained in Dulbecco's modified Eagle's medium (DMEM) supplemented with $10 \%$ (v/v) fetal bovine serum (FBS), $100 \mu \mathrm{g}$ streptomycin and 100 units penicillin (all Gibco; Thermo Fisher Scientific, Inc. Waltham, MA, USA). The cells were maintained in the growing medium at $37^{\circ} \mathrm{C}$ in a humidified $5 \% \mathrm{CO}_{2}$ atmosphere. At confluence, myoblasts were induced to fuse by changing the medium to medium supplemented with $2 \%$ horse serum (NQBB International Biological Corp., Hong Kong, China). The cells were maintained in $2 \%$ horse serum before the experiments. In starvation studies, the medium of the differentiated myotubes was replaced with serum-free medium for $48 \mathrm{~h}$ of incubation.

MTT cell activity assay. $\mathrm{C} 2 \mathrm{C} 12$ cells were cultured in 96-well plates $\left(5 \times 10^{4}\right.$ cells/plate) and were incubated for $24 \mathrm{~h}$ in DMEM containing $0.1 \%$ FBS. After differentiation of the $\mathrm{C} 2 \mathrm{C} 12$ cell line to form myotubes, control group cells did not receive any further treatment in addition to the incubation in medium supplemented with horse serum medium for $48 \mathrm{~h}$. Following treatment with $\operatorname{Rg} 1\left(10^{-4}, 10^{-3}, 10^{-2}\right.$ and $10^{-1} \mathrm{mM}$; Shanghai Yuanye Biotechnology Co., Ltd., Shanghai, China) for $48 \mathrm{~h}$, the starvation model was induced by incubation of the cells with serum-free basal medium for $48 \mathrm{~h}$. Myotubes were incubated with MTT solution (Invitrogen; Thermo Fisher Scientific, Inc.) for $4 \mathrm{~h}$ at $37^{\circ} \mathrm{C}$. Non-reduced MTT was removed by aspiration and the formazan crystals were dissolved in dimethyl sulfoxide ( $150 \mu \mathrm{l} / \mathrm{well})$ for $30 \mathrm{~min}$ at $37^{\circ} \mathrm{C}$. The formazan was quantified using spectroscopy using a microplate reader (Bio-Rad Laboratories, Inc., Hercules, CA, USA) at a wavelength of $490 \mathrm{~nm}$.
Western blot analysis. To assess the expression and phosphorylation levels of AKT, mTOR, FoxO1 and Fox3a, and the expression of atrogin-1 and MuRF-1,C2C12 cells were cultured in 6-well plates $\left(1 \times 10^{6}\right.$ cells/plate) after the differentiation of the $\mathrm{C} 2 \mathrm{C} 12$ cell line to form myotubes. For the specific inhibitor experiments, following pretreatment with the PI3K inhibitor, LY294002 (Merck KGaA, Darmstadt, Germany), at $25 \mu \mathrm{M}$ for $30 \mathrm{~min}$, the myotubes were cultured in serum-free medium in the absence or presence of $\operatorname{Rg} 1\left(10^{-4}, 10^{-3}, 10^{-2}\right.$ and $10^{-1} \mathrm{mM}$ ) for $5,10,30,60 \mathrm{~min}$ and $24 \mathrm{~h}$ at $37^{\circ} \mathrm{C}$ in a humidified $5 \% \mathrm{CO}_{2}$ atmosphere. For immunoblotting, cells were washed with ice-cold phosphate-buffered saline twice. Subsequently, the cells were immersed in $1 \mathrm{ml}$ precooled RIPA solution and PMSF (both Beijing Solarbio Science \& Technology Co., Ltd., Beijing, China) was added into the RIPA solution, at a final concentration of $1 \mathrm{mM}$, for protein extraction. The pyrolysis liquid was transferred to an EP tube that was precooled on ice for $30 \mathrm{~min}$. Following centrifugation at $13,000 \mathrm{x} g$ for $10 \mathrm{~min}$ $\left(4^{\circ} \mathrm{C}\right)$, the quantity of protein in the supernatants was detected using a bicinchoninic acid protein assay kit (Beijing Solarbio Science \& Technology Co., Ltd., Beijing, China). The lysates were collected $60 \mathrm{~min}$ later for western blot analysis.

The protein samples were separated by SDS-PAGE (6-8\%) and were transferred onto polyvinylidene fluoride membranes (EMD Millipore, Billerica, MA, USA). The amount of protein used per lane was $20 \mu \mathrm{g}$. Following blocking with 5\% non-fat milk for $1 \mathrm{~h}$ at room temperature, the membranes were incubated with primary antibodies specific for AKT (9272), mTOR (2972), FoxO1 (2880), FoxO3a (2497), phospho-AKT Ser473 (p-AKT; 4051), phospho-mTOR Ser2448 (p-mTOR; 2971), phospho-FoxO1 thr24 (p-FoxO1; 9464), phospho-FoxO3a thr32 (p-FoxO3a; 9464; all Cell Signaling Technology, Inc., Danvers, MA, USA), atrogin-1 (ab74023), MuRF-1 (ab172479; both Abcam, Shanghai, China) and $\beta$-actin (141205; ZSGB-BIO Technology Co. Ltd. Beijing China) overnight at $4^{\circ} \mathrm{C}$. All primary antibodies were used at a dilution of 1:1,000. Blots underwent a total of three 8-min washes with Tris-buffered saline with $0.1 \%$ Tween-20 and were then incubated with a secondary, immunoglobulin G antibody $(1: 8,000 ; 14708$; Cell Signaling Technology, Inc.) at room temperature for $1 \mathrm{~h}$. The membranes were washed as described above and the bands were scanned using the Tanon 5500 fully automatic digital gel image analysis system (Tanon Science \& Technology Co., Ltd., Shanghai, China).

Statistical analysis. All data are expressed as the mean \pm standard deviation. Statistical analyses were performed using analysis of variance and Tukey's post hoc tests using SigmaPlot version 10.0 software (Systat Software, Inc., San Jose, CA, USA) and $\mathrm{P}<0.05$ was considered to represent a statistically significant difference.

\section{Results}

Ginsenoside Rg1 increases the viability of mouse C2C12 myoblast cells in the starvation model. The viability of myoblast $\mathrm{C} 2 \mathrm{C} 12$ cells decreases when they are cultured during starvation (39). The results of the present study are consistent with this, as a reduction in the viability of the cells cultured in serum-free medium was observed compared with that in the 


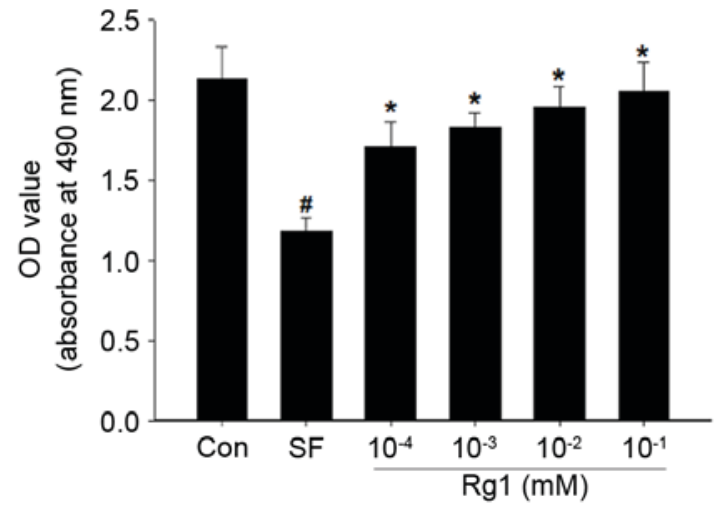

Figure 1. Effect of $\mathrm{Rg} 1$ on cell viability. On day 4, differentiated $\mathrm{C} 2 \mathrm{C} 12$ myotubes were incubated for $48 \mathrm{~h}$ in serum-free Dulbecco's modified Eagle medium. Differences in their viability, following a MTT assay were measured vs. an untreated control. Treatment with $10^{-4}, 10^{-3}, 10^{-2}$ and $10^{-1} \mathrm{mM} \operatorname{Rg} 1$ for $48 \mathrm{~h}$ resulted in a dose-dependent enhancement of cell viability. Results are presented as mean \pm standard deviation $(n=5)$. ${ }^{\#}<0.05$ vs. the Con group; ${ }^{*} \mathrm{P}<0.05$ vs. the SF group. Rg1, ginsenoside Rg1; OD, optical density; Con, control; SF, serum free.
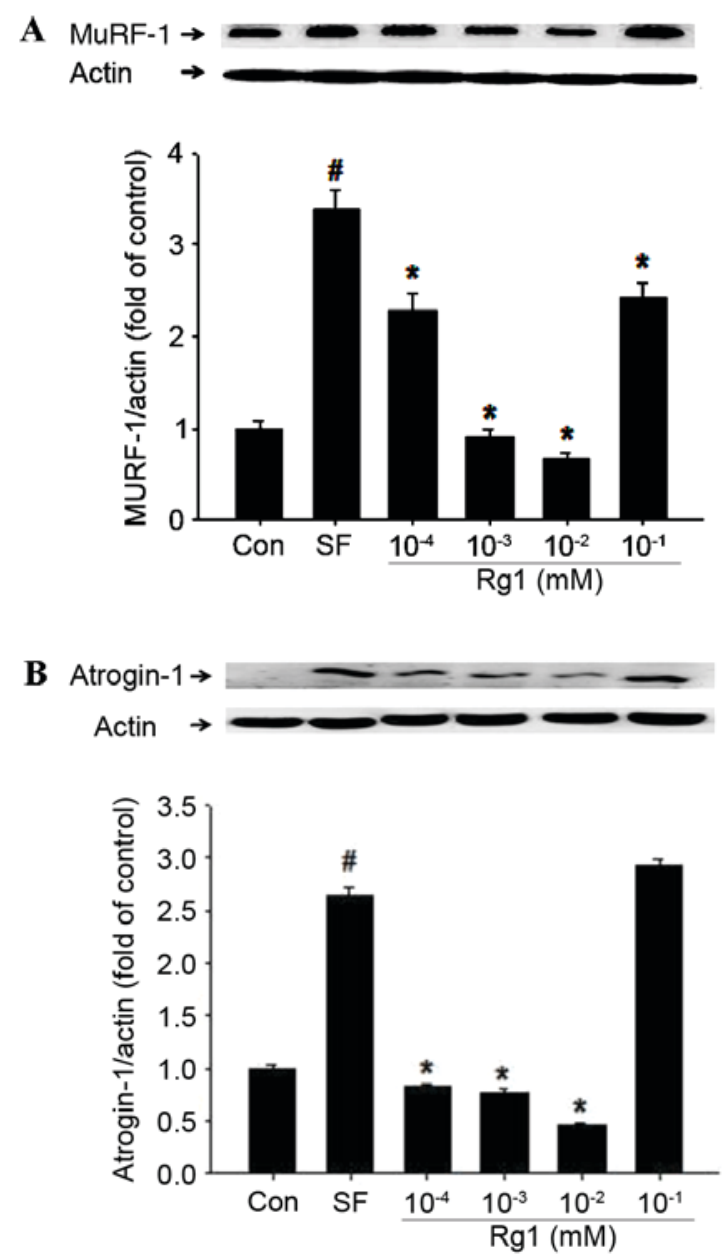

Figure 2. Effect of an increasing dose of $\mathrm{Rg} 1$ on the protein expression level of (A) MuRF1 and (B) atrogin-1 in serum-starved C2C12 cells. A significant dose-dependent suppressive effect on the expression of atrogin-1 and MuRF1 was observed following treatment with $10^{-4}, 10^{-3}$ and $10^{-2} \mathrm{mM} \mathrm{Rg} 1$. When $10^{-1} \mathrm{mM} \mathrm{Rg} 1$ was used, no significant effect on the expression of atrogin-1 observed. Results are presented as means \pm standard deviation, $(\mathrm{n}=6$ for each group). ${ }^{\#} \mathrm{P}<0.05$ vs. the Con group; ${ }^{*} \mathrm{P}<0.05$ vs. the $\mathrm{SF}$ group by analysis of variance and Tukey's post hoc tests. Rg1, ginsenoside Rg1; MuRF1, muscle ring finger protein; atrogin-1, muscle atrophy F-box; Con, control; SF, serum free; Actin, $\beta$-actin.

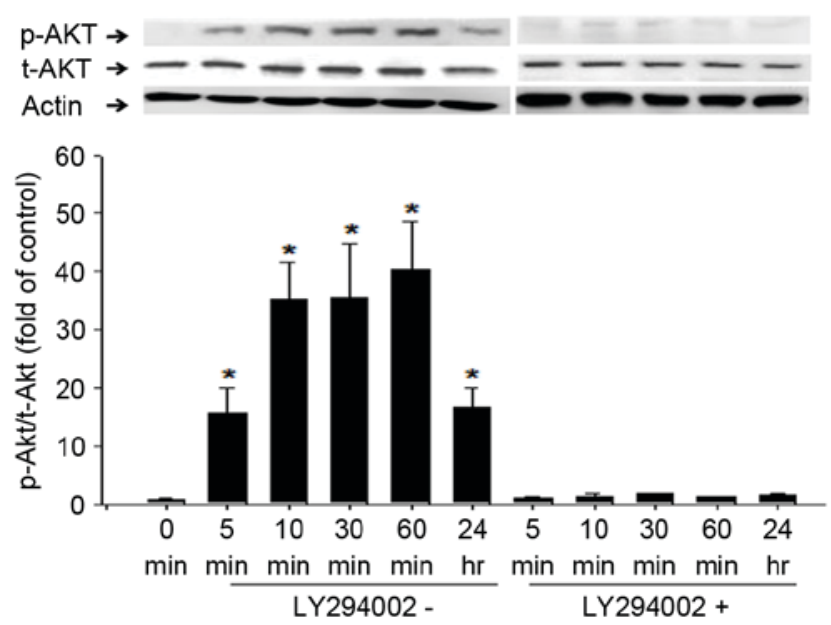

Figure 3. Rg1-induced phosphorylation of AKT in C2C12 cells over $24 \mathrm{~h}$ Differentiated $\mathrm{C} 2 \mathrm{C} 12$ cells were cultured with serum-free basal medium for $12 \mathrm{~h}$ prior to treatment with $10^{-4} \mathrm{mM} \mathrm{Rg} 1$ in the presence or absence of LY294002, a PI3K inhibitor. Cells were collected 5, 10, 30 and $60 \mathrm{~min}$ and $24 \mathrm{~h}$ later for western blot analysis of AKT phosphorylation at Ser473. The western blot analysis results are presented using representative images and the ratio of p-AKT to t-AKT levels at different time points is indicated using combined quantitative data. Results are presented as means \pm standard deviation, ( $\mathrm{n}=4$ for each group). ${ }^{*} \mathrm{P}<0.01$ vs. 0 min by analysis of variance and Tukey post hoc tests. AKT, protein kinase B; p-, phosphorylated; t-, total; Rg1, ginsenoside Rg1; PI3K, phosphatidylinositol 3-kinase; Ser, Serine; Actin, $\beta$-actin.

control group (Fig. 1). However, treatment with $\mathrm{Rg} 1$ increased the viability of the starved $\mathrm{C} 2 \mathrm{C} 12$ cells in a dose-dependent manner. Treatment with $10^{-1} \mathrm{mM} \operatorname{Rg} 1$ restored the viability of cells to that of the cells in the normal medium. The results of the present study suggest that ginsenoside $\operatorname{Rg} 1$ promoted the viability of mouse myoblast cells in the starvation model.

Rg1 inhibits the expression of atrogin-1 and MuRF-1 in C2C12 cells in the starvation model. In order to assess how $\mathrm{Rg} 1$ increased the viability of $\mathrm{C} 2 \mathrm{C} 12$ cells in the starvation model, the present study examined its effects on the expression of MuRF1 and atrogin-1 (Fig. 2). The results indicated that treatment with $10^{-2} \mathrm{mM} \operatorname{Rg} 1$ had the largest significant inhibitory effect on atrogin-1 and MuRF1 expression in $\mathrm{C} 2 \mathrm{C} 12$ cells $(\mathrm{P}<0.05)$. However, significantly reduced expression was also observed in the $10^{-4}$ and $10^{-3} \mathrm{mM} \mathrm{Rg} 1$ treatment groups $(\mathrm{P}<0.05)$. The expression of atrogin-1 and MuRF1 was less strongly inhibited by treatment with $10^{-1} \mathrm{mM} \mathrm{Rg} 1$. Therefore, $10^{-2} \mathrm{mM}$ was considered to be the optimal dose of $\mathrm{Rg} 1$ for inhibiting the expression of atrogin-1 and MuRF1 and increasing the viability of $\mathrm{C} 2 \mathrm{C} 12$ cells in the starvation model.

Rg1 stimulates PI3K-dependent phosphorylation of AKT and FoxO in C2C12 cells in the starvation model. The inhibition of atrogin-1 and MuRF1 expression is primarily caused by the phosphorylation of the transcription factors, AKT and FoxO (40). The present study therefore assessed whether Rg1 is able to change the phosphorylation levels of AKT and FoxO. The cells were treated with $\mathrm{Rg} 1$ at various time points $(0,5,10$, 30 , and $60 \mathrm{~min}$ and $24 \mathrm{~h}$ ) for western blot analysis of targeted protein phosphorylations. Changes in cellular AKT phosphorylation appeared as early as $5 \mathrm{~min}$ and reached a peak at $60 \mathrm{~min}$ 
A
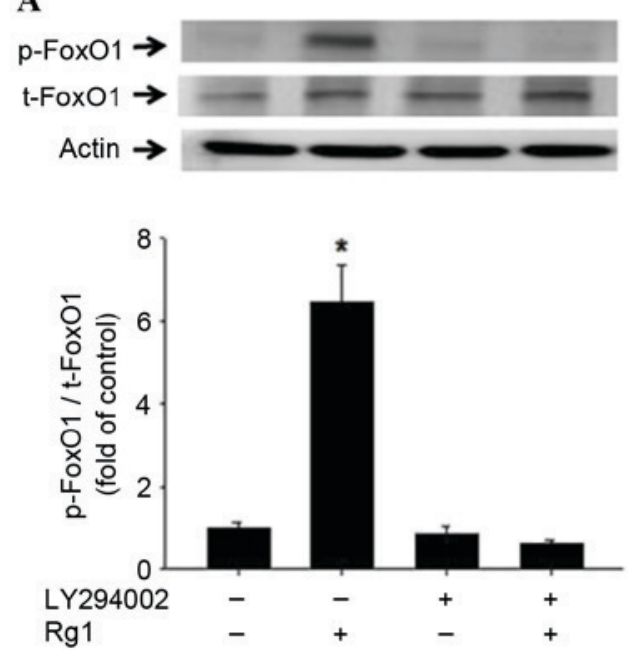

B
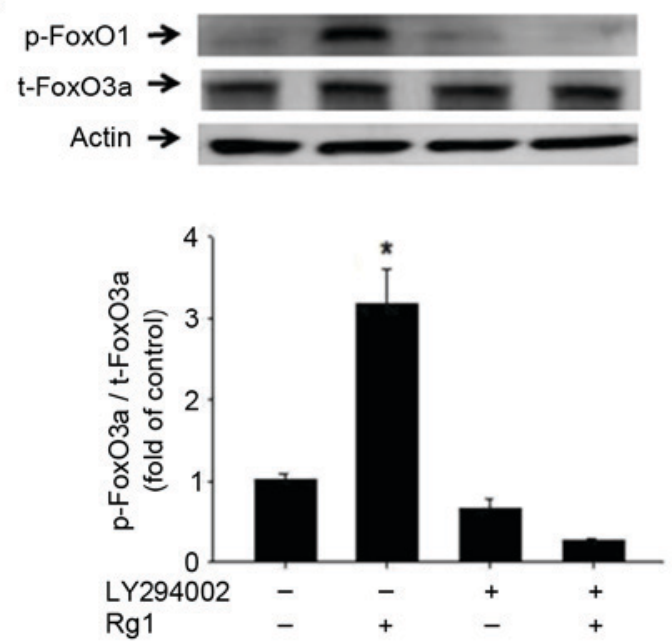

Figure 4. Phosphorylation of FoxO1 and FoxO3a in $\mathrm{C} 2 \mathrm{C} 12$ cells following Rg1 treatment. Levels of (A) FoxO1 and (B) FoxO3a phosphorylation in cultured $\mathrm{C} 2 \mathrm{C} 12$ cells, incubated in the presence of $10^{-2} \mathrm{mM} \mathrm{Rg} 1$ and/or the PI3K inhibitor LY294002. LY294002 was added 30 min prior to the addition of $10^{-2} \mathrm{mM}$ $\mathrm{Rg} 1$. Western blot analysis results are presented using representative images and the p-FoxO1:t-FoxO1 and p-FoxO3a:t-FoxO3a ratios are demonstrated using combined quantitative data. Results are presented as the mean \pm standard deviation of four experiments. ${ }^{~} \mathrm{P}<0.05$ vs. Rg1 group by analysis of variance and Tukey's post hoc tests. FoxO1, forkhead transcription factor O, subtype 1; FoxO3a, forkhead transcription factor O, subtype 3a; Rg1, ginsenoside Rg1; PI3K, phosphatidylinositol 3-kinase; LY294002, inhibitor of PI3K; p-, phosphorylated; t-, total; Actin, $\beta$-actin.

A
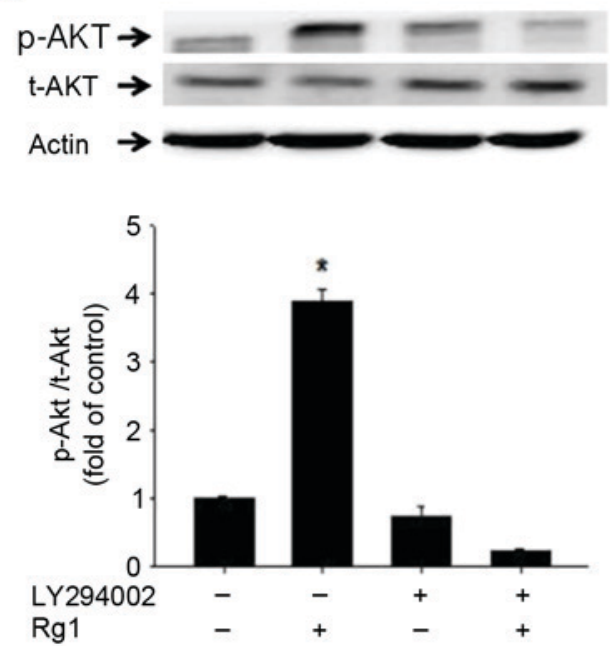

B
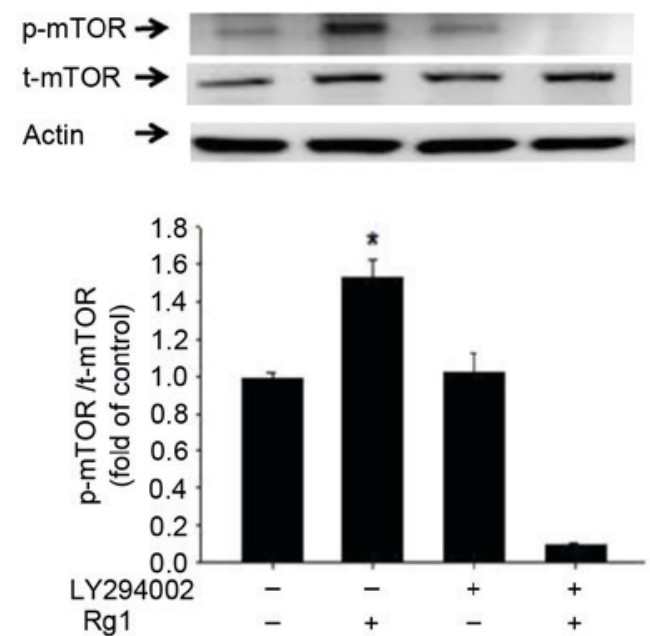

Figure 5. Effect of Rg1 on the phosphorylation of AKT and mTOR in C2C12 cells. Phosphorylation of (A) AKT and (B) mTOR following $12 \mathrm{~h}$ culture in serum-free basal medium. Cells were incubated in the presence of $10^{-2} \mathrm{mM} \mathrm{Rg} 1$ and/or the PI3K inhibitor LY294002. LY294002 was added 30 min prior to treatment with Rg1. The lysates were collected 60 min later for western blot analysis. Western blot analysis results are presented using representative images and the p-Akt:t-Akt and the p-mTOR:t-mTOR ratios are demonstrated using combined quantitative data. Results are presented as mean \pm standard deviation ( $\mathrm{n}=4$ for each group). "P<0.05 vs. Rg1 group by analysis of variance and Tukey's post hoc tests. Rg1, ginsenoside Rg1; AKT, protein kinase B; mTOR, mammalian target of rapamycin; PI3K, phosphatidylinositol 3-kinase; LY294002, inhibitor of PI3K; p-, phosphorylated; t-, total; Actin, $\beta$-actin.

after the intervention before decreasing. PI3K inhibition by LY294002 completely abolished this Rg1-induced phosphorylation at the indicated time points. The results demonstrated that the phosphorylation levels of AKT, FoxO1 and FoxO3a were all increased following the treatment of $\mathrm{C} 2 \mathrm{C} 12$ cells in serum-free medium with $10^{-2} \mathrm{mM} \mathrm{Rg}$, whereas the expression levels of AKT, FoxO1 and FoxO3a were not changed by treatment with Rg1 (Figs. 3 and 4).

The phosphorylation of AKT and FoxO is known to be regulated by PI3K $(4,41)$. Therefore, the present study investigated the effects of LY294002, an inhibitor of PI3K. C2C12 cells in serum-free medium were treated with Rg1 and LY294002 individually and together. The Rg1-induced phosphorylation levels of AKT, FoxO1 and FoxO3a were significantly impaired by treatment with LY294002 ( $<<0.05$; Figs. 3 and 4). These results indicate that $\mathrm{Rg} 1$ promoted the phosphorylation of AKT, FoxO1 and FoxO3a and was dependent on PI3K activity.

Rgl activates the PI3K-dependent phosphorylation of mTOR in C2C12 cells of the starvation model. As a downstream molecule of AKT, mTOR serves a key role in protein synthesis (42-44). The results of the present study demonstrated that $\mathrm{Rg} 1$ upregulated the phosphorylation of mTOR in $\mathrm{C} 2 \mathrm{C} 12$ cells in the starvation model. The PI3K inhibitor, 
LY294002 was observed to inhibit the mTOR phosphorylation induced by $\mathrm{Rg} 1$ (Fig. 5). This indicates that Rg1 promoted the PI3K-dependent phosphorylation of mTOR in C2C12 cells in the starvation model.

\section{Discussion}

$\mathrm{Rg} 1$ has been indicated to have an effect on the function of human diseases via anti-inflammatory and antioxidant defense systems (45-55). The present study demonstrated that $\operatorname{Rg} 1$ increased the viability of muscle cells within a starvation model, by inhibiting protein degradation via the AKT/FoxO pathway and promoting protein synthesis by the mTOR pathway.

The viability of muscle cells is a key factor for resistance to muscle atrophy. When the rate of protein degradation exceeds the rate of protein synthesis in adult tissues, muscle atrophy occurs. The ubiquitin-proteasome pathway is one of most important protein degradation pathways, which is activated during muscle atrophy and contributes to the loss of muscle mass. The ubiquitin proteasome system is controlled by the modulation of rate-limiting enzyme expression in proteolytic systems, including atrogin-1/MAFbx and MuRF-1 (21,56-60).

Atrogin-1/MAFbx and MuRF-1 knockout mice have been demonstrated to be resistant to muscle atrophy induced by denervation (61). MuRF-1 knockout mice are also resistant to dexamethasone-induced muscle atrophy (62), while knockdown of atrogin-1 spares muscle mass in fasting animal models (63). Furthermore, MuRF1 ubiquitinates a number of structural proteins in the muscle including actin (64), myosin heavy chains $(65,66)$, troponin I $(67)$, myosin binding protein $\mathrm{C}$ and myosin light chains 1 and 2 (68). Atrogin-1 promotes degradation of MyoD, a key muscle transcription factor and eukaryotic translation initiation factor 3, subunit F, an important activator of protein synthesis $(69,70)$. Therefore, high expression of atrogin-1/MAFbx and MuRF-1 may be crucial factors in muscle atrophy.

The insulin-AKT pathway negatively regulates FoxO transcription factors, which. were the first to be identified as critical for the process of atrophy (9). It has been indicated that hypertrophy may be induced in myotubes by the activation of protein synthesis through the AKT/mTOR pathway (21).

Cell apoptosis is closely related to muscle protein degradation in cells, and previous reports have indicated that apoptosis signaling is essential, and precedes protein degradation, in wasting skeletal muscle during catabolic conditions $(40,71)$. These previous reports highlight that an apoptotic signal is necessary for the activation of skeletal muscle protein degradation. Activation of muscle protein hydrolysis resulting in muscle atrophy is a complex process, and it has been demonstrated that there are various mechanisms involved, including mechanisms related to cell apoptosis signaling molecules (40). A review article by Argilés et al (40) also demonstrated that the inhibition of apoptosis is able to inhibit protein degradation. In the condition of health, skeletal muscle protein metabolism, protein synthesis and protein decomposition does not require caspase-3 activated protein hydrolysis. In fact, an in vitro experiment demonstrated that using the specific compound,
Ac-DEVD-CHO (a caspase-3 inhibitor), did not inhibit the degradation of proteins of the basement membrane (71). However, in the case of catabolism, muscle fibers in excess protein degradation may use the above inhibitors to block the degradation of protein (71). This conclusion is also supported by experimental acute induced diabetes (71). In view of the above, under the condition of catabolism, excessive protein degradation is related to the activation of apoptotic protease caspase-3 (40). As previously demonstrated, the inhibition of apoptosis may provide a potential target for a drug for the treatment of muscular dystrophy (71). This will be the focus of future research.

In conclusion, the current study observed that Rg1 treatment has an inhibitory effect on Atrogin-1/MAFbx and MuRF1 translation via the activation of Akt, mTOR and FoxO phosphorylation, which prevents starvation-induced muscle cell death. The present study therefore provides a theoretical basis for the use of Rg1 to treat muscle atrophy in a clinical setting.

\section{Acknowledgements}

The present study was supported by the National Natural Science Fund of China (grant no. 51478096) and Jilin Province Science and Technology Research Projects (grant no. 20140204059YY).

\section{References}

1. Kawai N, Hirasaka K, Maeda T, Haruna M, Shiota C, Ochi A, Abe T, Kohno S, Ohno A, Teshima-Kondo S, et al: Prevention of skeletal muscle atrophy in vitro using anti-ubiquitination oligopeptide carried by atelocollagen. Biochim Biophy Acta 1853: 873-880, 2015.

2. Langen RC, Gosker HR, Remels AH and Schols AM: Triggers and mechanisms of skeletal muscle wasting in chronic obstructive pulmonary disease. Int J Biochem Cell Biol 45: 2245-2256, 2013.

3. Joassard OR, Durieux AC and Freyssenet DG: $\beta 2$-Adrenergic agonists and the treatment of skeletal muscle wasting disorders. Int J Biochem Cell Biol 45: 2309-2321, 2013.

4. Wang DT, Yin Y, Yang YJ, Lv PJ, Shi Y, Lu L and Wei LB: Resveratrol prevents TNF- $\alpha$-induced muscle atrophy via regulation of Akt/mTOR/FoxO1 signaling in $\mathrm{C} 2 \mathrm{C} 12$ myotubes. Int Immunopharmacol 19: 206-213, 2014.

5. Lecker SH, Jagoe RT, Gilbert A, Gomes M, Baracos V, Bailey J, Price SR, Mitch WE and Goldberg AL: Multiple types of skeletal muscle atrophy involve a common program of changes in gene expression. FASEB J 18: 39-51, 2004.

6. Langen RC, Gosker HR, Remels AH and Schols AM: Triggers and mechanisms of skeletal muscle wasting in chronic obstructive pulmonary disease. Int J Biochem Cell Biol 45: 2245-2256, 2013.

7. Feng W, Tu JC, Pouliquin P, Cabrales E, Shen X, Dulhunty A, Worley PF, Allen PD and Pessah IN: Dynamic regulation of ryanodine receptor type 1 (RyR1) channel activity by Homer 1 . Cell Calcium 43: 307-314, 2008.

8. Joassard OR, Amirouche A, Gallot YS, Desgeorges MM, Castells J, Durieux AC, Berthon P and Freyssenet DG: Regulation of Akt-mTOR, ubiquitin-proteasome and autophagy-lysosome pathways in response to formoterol administration in rat skeletal muscle. Int J Biochem Cell Biol 45: 2444-2455, 2013.

9. Sandri M: Protein breakdown in muscle wasting: Role of autophagy-lysosome and ubiquitin-proteasome. Int J Biochem Cell Biol 45: 2121-2129, 2013.

10. Kawai N, Hirasaka K, Maeda T, Haruna M, Shiota C, Ochi A, Abe T, Kohno S, Ohno A, Teshima-Kondo S, et al: Prevention of skeletal muscle atrophy in vitro using anti-ubiquitination oligopeptide carried by atelocollagen. Biochim Biophys Acta 1853: 873-880, 2015. 
11. Kazi AA, Hong-Brown L, Lang SM and Lang CH: Deptor knockdown enhances mTOR activity and protein synthesis in myocytes and ameliorates disuse muscle atrophy. Mol Med 17: 925-936, 2011.

12. Zheng B, Ohkawa S, Li HY, Roberts-Wilson TK and Price SR: FOXO3a mediates signaling crosstalk that coordinates ubiquitin and atrogin-1/MAFbx expression during glucocorticoid-induced skeletal muscle atrophy. FASEB J 24: 2660-2669, 2010.

13. You JS, Lincoln HC, Kim CR, Frey JW, Goodman CA, Zhong XP and Hornberger TA: The role of diacylglycerol kinase $\xi$ and phosphatidic acid in the mechanical activation of mammalian target of rapamycin (mTOR) signaling and skeletal muscle hypertrophy. J Biol Chem 289: 1551-1563, 2014.

14. Moylan JS, Smith JD, Chambers MA, McLoughlin TJ and Reid MB: TNF induction of atrogin-1/MAFbx mRNA depends on Foxo4 expression but not AKT-Foxo1/3 signaling. Am J Physiol Cell Physiol 295: C986-C993, 2008.

15. Tisdale MJ: The ubiquitin-proteasome pathway as a therapeutic target for muscle wasting. J Support Oncol 3: 209-217, 2005.

16. Argiles JA, López-Soriano FJ and Busquets S: Apoptosis signalling is essential and precedes protein degradation in wasting skeletal muscle during catabolic conditions. Int J Biochem Cell Biol 40: 1674-1678, 2008.

17. Wray CJ, Mammen JM, Hershko DD and Hasselgren PO: Sepsis upregulates the gene expression of multiple ubiquitin ligases in skeletal muscle. Int J Biochem Cell Biol 35: 698-705, 2003.

18. Tong JF, Yan X, Zhu MJ and Du M: AMP-activated protein kinase enhances the expression of muscle-specific ubiquitin ligases despite its activation of IGF-1/Akt signaling in $\mathrm{C} 2 \mathrm{C} 12$ myotubes. J Cell Biochem 108: 458-468, 2009.

19. Hershko A and Ciechanover A: The ubiquitin system. Annu Rev Biochem 67: 425-479, 1998.

20. Argilés JM, López-Soriano FJ and Busquets S: Apoptosis signalling is essential and precedes protein degradation in wasting skeletal muscle during catabolic conditions. Int J Biochem Cell Biol 40: 1674-1678, 2008.

21. Stitt TN, Drujan D, Clarke BA, Panaro F, Timofeyva Y, Kline WO, Gonzalez M, Yancopoulos GD and Glass DJ: The IGF-1/PI3K/Akt pathway prevents expression of muscle atrophy-induced ubiquitin ligases by inhibiting FOXO transcription factors. Mol Cell 14: 395-403, 2004.

22. Sandri M, Sandri C, Gilbert A, Skurk C, Calabria E, Picard A, Walsh K, Schiaffino S, Lecker SH and Goldberg AL: Foxo transcription factors induce the atrophy-related ubiquitin ligase atrogin-1 and cause skeletal muscle atrophy. Cell 117: 399-412, 2004.

23. Baviera AM, Zanon NM, Navegantes LC and Kettelhut IC: Involvement of $\mathrm{cAMP} / \mathrm{Epac} / \mathrm{PI} 3 \mathrm{~K}$-dependent pathway in the antiproteolytic effect of epinephrine on rat skeletal muscle. Mol Cell Endocrinol 315: 104-112, 2010.

24. Sharp ZD and Bartke A: Evidence for down-regulation of phosphoinositide 3-kinase/Akt/mammalian target of rapamycin (PI3K/Akt/mTOR)-dependent translation regulatory signaling pathways in Ames dwarf mice. J Gerontol A Biol Sci Med Sci 60: 293-300, 2005.

25. Goodman CA, Mayhew DL and Hornberger TA: Recent progress toward understanding the molecular mechanisms that regulate skeletal muscle mass. Cell Signal 23: 1896-1906, 2011.

26. Kimura K, Cheng XW, Inoue A, Hu LN, Koike T and Kuzuya M: $\beta$-Hydroxy- $\beta$-methylbutyrate facilitates PI3K/Akt-dependent mammalian target of rapamycin and FoxO1/3a phosphorylations and alleviates tumor necrosis factor $\alpha /$ interferon $\gamma$-induced MuRF-1 expression in C2C12 cells. Nutr Res 34: 368-374, 2014.

27. Jia L, Li YF, Wu GF, Song ZY, Lu HZ, Song CC, Zhang QL, Zhu JY, Yang GS and Shi XE: MiRNA-199a-3p regulates C2C12 myoblast differentiation through IGF-1/AKT/ mTOR signal pathway. Int J Mol Sci 15: 296-308, 2013.

28. Risson V, Mazelin L, Roceri M, Sanchez H, Moncollin V, Corneloup C, Richard-Bulteau H, Vignaud A, Baas D, Defour A, et al: Muscle inactivation of mTOR causes metabolic and dystrophin defects leading to severe myopathy. J Cell Biol 187: 859-874, 2009.

29. Sievenpiper JL, Arnason JT, Leiter LA and Vuksan V: Variable effects of American ginseng: A batch of American ginseng (Panax quinquefolius L.) with a depressed ginsenoside profile does not affect postprandial glycemia. Eur J Clin Nutr 57: 243-248, 2003

30. Um JY, Chung HS, Kim MS, Na HJ, Kwon HJ, Kim JJ, Lee KM, Lee SJ, Lim JP, Do KR, et al: Molecular authentication of Panax ginseng species by RAPD analysis and PCR-RFLP. Biol Pharm Bull 24: 872-875, 2001
31. Hou CW, Lee SD, Kao CL, Cheng IS, Lin YN, Chuang SJ, Chen CY, Ivy JL, Huang CY and Kuo CH: Improved inflammatory balance of human skeletal muscle during exercise after supplementations of the ginseng-based steroid Rg1. PLoS One 10: e0116387, 2015.

32. Yu SH, Huang HY, Korivi M, Hsu MF, Huang CY, Hou CW, Chen CY, Kao CL, Lee RP, Lee SD and Kuo CH: Oral Rg1 supplementation strengthens antioxidant defense system against exercise-induced oxidative stress in rat skeletal muscles. J Int Soc Sport Nutr 9: 23, 2012.

33. Yang XD, Yang YY, Ouyang DS and Yang GP: A review of biotransformation and pharmacology of ginsenoside compound K. Fitoterapia 100: 208-220, 2015.

34. Liu QF, Deng ZY, Ye JM, He AL and Li SS: Ginsenoside Rg1 protects chronic cyclosporin a nephropathy from tubular cell apoptosis by inhibiting endoplasmic reticulum stress in rats. Transplant Proc 47: 566-569, 2015.

35. Kim WK, Song SY, Oh WK, Kaewsuwan S, Tran TL, Kim WS and Sung JH: Wound-healing effect of ginsenoside Rd from leaves of Panax ginseng via cyclic AMP-dependent protein kinase pathway. Eur J Pharmacol 702: 285-293, 2013.

36. Qi B, Liu L, Zhang H, Zhou GX, Wang S, Duan XZ, Bai XY, Wang SM and Zhao DQ: Anti-fatigue effects of proteins isolated from Panax quinquefolium. J Ethnopharmacol 153: 430-434, 2014.

37. Zhuang CL, Mao XY, Liu S, Chen WZ, Huang DD, Zhang CJ, Chen BC, Shen X and Yu Z: Ginsenoside Rb1 improves postoperative fatigue syndrome by reducing skeletal muscle oxidative stress through activation of the PI3K/Akt/Nrf2 pathway in aged rats. Eur J Pharmacol 740: 480-487, 2014.

38. Wei HJ, Yang HH, Chen CH, Lin WW, Chen SC, Lai PH, Chang Y and Sung HW: Gelatin microspheres encapsulated with a nonpeptide angiogenic agent, ginsenoside Rg1, for intramyocardial injection in a rat model with infarcted myocardium. J Control Release 120: 27-34, 2007.

39. Sato S, Ogura Y and Kumar A: TWEAK/Fn14 signaling axis mediates skeletal muscle atrophy and metabolic dysfunction. Front Immunol 5: 18, 2014.

40. Argilés JM, López-Soriano FJ and Busquets S: Apoptosis signalling is essential and precedes protein degradation in wasting skeletal muscle during catabolic conditions. Int J Biochem Cell Biol 40: 1674-1678, 2008.

41. Thomas MP, Mills J and Engelbrecht AM: Phosphatidylinositol3-kinase (PI3K) activity decreases in C2C12 myotubes during acute simulated ischemia at a cost to their survival. Life Sci 91: 44-53, 2012.

42. Giresi PG, Stevenson EJ, Theilhaber J, Koncarevic A, Parkington J, Fielding RA and Kandarian SC: Identification of a molecular signature of sarcopenia. Physiol Genomics 21: 253-263, 2005.

43. Kandarian SC and Jackman RW: Intracellular signaling during skeletal muscle atrophy. Muscle Nerve 33: 155-165, 2006.

44. Schulze PC, Fang J, Kassik KA, Gannon J, Cupesi M, MacGillivray C, Lee RT and Rosenthal N: Transgenic overexpression of locally acting insulin-like growth factor-1 inhibits ubiquitin-mediated muscle atrophy in chronic left-ventricular dysfunction. Circ Res 97: 418-426, 2005.

45. Kim WK, Song SY, Oh WK, Kaewsuwan S, Tran TL, Kim WS and Sung JH: Wound-healing effect of ginsenoside Rd from leaves of Panax ginseng via cyclic AMP-dependent protein kinase pathway. Eur J Pharmacol 702: 285-293, 2013.

46. Attele AS, Wu JA and Yuan CS: Ginseng pharmacology: Multiple constituents and multiple actions. Biochem Pharmacol 58: 1685-1693, 1999

47. Chen X: Cardiovascular protection by ginsenosides and their nitric oxide releasing action. Clin Exp Pharmacol Physiol 23: 728-732, 1996.

48. Gillis CN: Panax ginseng pharmacology: A nitric oxide link? Biochem Pharmacol 54: 1-8, 1997.

49. Nag SA, Qin JJ, Wang W, Wang MH, Wang H and Zhang R: Ginsenosides as anticancer agents: In vitro and in vivo activities, structure-activity relationships and molecular mechanisms of action. Front Pharmacol 3: 25, 2012.

50. Xie JT, Mehendale S and Yuan CS: Ginseng and diabetes. Am J Chin Med 33: 397-404, 2005.

51. Hwang JT, Kim SH, Lee MS, Kim SH, Yang HJ, Kim MJ, Kim HS, Ha J, Kim MS and Kwon DY: Anti-obesity effects of ginsenoside $\mathrm{Rh} 2$ are associated with the activation of AMPK signaling pathway in 3T3-L1 adipocyte. Biochem Biophys Res Commun 364: 1002-1008, 2007. 
52. Cho WC, Chung WS, Lee SK, Leung AW, Cheng CH and Yue KK: Ginsenoside Re of Panax ginseng possesses significant antioxidant and antihyperlipidemic efficacies in streptozotocin-induced diabetic rats. Eur J Pharmacol 550: 173-179, 2006.

53. Shang W, Yang Y, Zhou L, Jiang B, Jin H and Chen M: Ginsenoside Rb1 stimulates glucose uptake through insulin-like signaling pathway in 3T3-L1 adipocytes. J Endocrinol 198: 561-569, 2008

54. Song Z, Moser C, Wu H, Faber V, Kharazmi A and Høiby N Cytokine modulating effect of ginseng treatment in a mouse model of Pseudomonas aeruginosa lung infection. J Cyst Fibros 2: 112-119, 2003.

55. Lee E, Ko E, Lee J, Rho S, Ko S, Shin MK, Min BI, Hong MC Kim SY and Bae H: Ginsenoside Rg1 enhances CD4(+) T-cel activities and modulates Th1/Th2 differentiation. Int Immunopharmacol 4: 235-244, 2004.

56. Foletta VC, White LJ, Larsen AE, Léger B and Russell AP: The role and regulation of MAFbx/atrogin-1 and MuRF1 in skeletal muscle atrophy. Pflugers Arch 461: 325-335, 2011.

57. Jagoe RT and Goldberg AL: What do we really know about the ubiquitin-proteasome pathway in muscle atrophy? Curr Opin Clin Nutr Metab Care 4: 183-190, 2001.

58. Wray CJ, Mammen JM, Hershko DD and Hasselgren PO: Sepsis upregulates the gene expression of multiple ubiquitin ligases in skeletal muscle. Int J Biochem Cell Biol 35: 698-705, 2003.

59. Hershko A: The ubiquitin system. Springer US, 1998.

60. Krawiec BJ, Nystrom GJ, Frost RA, Jefferson LS and Lang CH: AMP-activated protein kinase agonists increase mRNA content of the muscle-specific ubiquitin ligases MAFbx and MuRF1 in C2C12 cells. Am J Physiol Endocrinol Metab 292: E1555-E1567, 2007.

61. Bodine SC, Latres E, Baumhueter S, Lai VK, Nunez L, Clarke BA, Poueymirou WT, Panaro FJ, Na E, Dharmarajan K, et al: Identification of ubiquitin ligases required for skeletal muscle atrophy. Science 294: 1704-1708, 2001.

62. Baehr LM, Furlow JD and Bodine SC: Muscle sparing in muscle RING finger 1 null mice: Response to synthetic glucocorticoids. J Physiol 589: 4759-4776, 2011.
63. Cong H, Sun L, Liu C and Tien P: Inhibition of atrogin-1/MAFbx expression by adenovirus-delivered small hairpin RNAs attenuates muscle atrophy in fasting mice. Hum Gene Ther 22: 313-324, 2011.

64. Polge C, Heng AE, Jarzaguet M, Ventadour S, Claustre A, Combaret L, Béchet D, Matondo M, Uttenweiler-Joseph S, Monsarrat $\mathrm{B}$, et al: Muscle actin is polyubiquitinylated in vitro and in vivo and targeted for breakdown by the E3 ligase MuRF1. FASEB J 25: 3790-3802, 2011.

65. Clarke BA, Drujan D, Willis MS, Murphy LO, Corpina RA, Burova E, Rakhilin SV, Stitt TN, Patterson C, Latres E and Glass DJ: The E3 Ligase MuRF1 degrades myosin heavy chain protein in dexamethasone-treated skeletal muscle. Cell Metab 6: 376-385, 2007.

66. Fielitz J, Kim MS, Shelton JM, Latif S, Spencer JA, Glass DJ, Richardson JA, Bassel-Duby R and Olson EN: Myosin accumulation and striated muscle myopathy result from the loss of muscle RING finger 1 and 3. J Clin Invest 117: 2486-2495, 2007.

67. Kedar V, McDonough H, Arya R, Li HH, Rockman HA and Patterson C: Muscle-specific RING finger 1 is a bona fide ubiquitin ligase that degrades cardiac troponin I. Proc Natl Acad Sci USA 101: 18135-18140, 2004.

68. Cohen S, Brault JJ, Gygi SP, Glass DJ, Valenzuela DM, Gartner C, Latres E and Goldberg AL: During muscle atrophy, thick, but not thin, filaments components are degraded by MuRF1-dependent ubiquitylation. J Cell Biol 185: 1083-1095, 2009.

69. Csibi A, Cornille K, Leibovitch MP, Poupon A, Tintignac LA, Sanchez AM and Leibovitch SA: The translation regulatory subunit eIF3f controls the kinase-dependent mTOR signaling required for muscle differentiation and hypertrophy in mouse. PLoS One 5: e8994, 2010.

70. Tintignac LA, Lagirand J, Batonnet S, Sirri V, Leibovitch MP and Leibovitch SA: Degradation of MyoD mediated by the SCF (MAFbx) ubiquitin ligase. J Biol Chem 280: 2847-2856, 2005.

71. Du J, Wang X, Miereles C, Bailey JL, Debigare R, Zheng B, Price SR and Mitch WE: Activation of caspase-3 is an initial step triggering accelerated muscle proteolysis in catabolic conditions. J Clin Invest 113: 115-123, 2004 